\title{
STUDY OF THE EFFECT OF CHEMICAL POLLUTION WITH COAL- FIRED POWER PLANT ON THE FISH OF LAKE KENON (TRANS-BAIKAL TERRITORY, RUSSIA)
}

\author{
Gazhit Ts. Tsybekmitova ๑ , Evgeniya P. Gorlacheva @ , Nataliya A. Tashlykova @ \\ Institute of Natural Resources, Ecology and Cryology SB RAS, Chita, Russian Federation
}

Manuscript received: November 6, 2020

Revised version: January 26, 2021

\begin{abstract}
Tsybekmitova G.Ts., Gorlacheva E.P., Tashlykova N.A., 2021. Study of the effect of chemical pollution with coal-fired power plant on the fish of Lake Kenon (Trans-Baikal territory, Russia). Quaestiones Geographicae 40(1), Bogucki Wydawnictwo Naukowe, Poznań, pp. 51-62. 5 tables, 6 figs.

ABSTRACT: In this study, contamination of potentially toxic elements ( $\mathrm{Cr}, \mathrm{Mn}, \mathrm{Cu}, \mathrm{Zn}, \mathrm{Hg}$ and $\mathrm{Pb}$ ) and species dominant in the fish community of Lake Kenon - Carassius auratus gibelio (Bloch 1782) and Perca fluviatilis (Linnaeus 1758) - were investigated. Chemical elements in samples were determined by atomic emission spectrometry (iCAP-6500, Thermo Scientific, USA) and mass spectrometry (X-7, Thermo Elemental, USA). It was reported that water in Lake Kenon contained low concentrations of the studied metals. The bottom sediments are enriched with $\mathrm{Mn}, \mathrm{Zn}, \mathrm{Hg}$ and $\mathrm{Pb}$. Bioaccumulation factors of chemical elements accumulated from the surrounding water for P. fluviatus and C. auratus gibelio in descending order are as follows: $\mathrm{Zn}>\mathrm{Pb}>\mathrm{Hg}>\mathrm{Cu}$. P. fluviatus accumulates $\mathrm{Hg}$ in equal measure from both water and bottom sediments. Manganese and mercury are accumulated in the muscles of C. auratus gibelio from bottom sediments. The high accumulation ratio of $\mathrm{Zn}$ and $\mathrm{Hg}$ in C. auratus gibelio was obtained from Chara sp. (24 times) and Chironomus spp. (38 times), respectively. High accumulation ratio of $\mathrm{Zn}$ (26 times) and $\mathrm{Hg}$ (29 times) in P. fluviatus was obtained from amphipods. At the same time, $\mathrm{Hg}$ in P. fluviatus muscles was accumulated at high level from Chironomus spp. (67 times). In this way, management decisions for mitigation practices in Lake Kenon should be focussed on for the disposal of wastewater from the ash dump contaminated with chemical elements.
\end{abstract}

KEY wORDS: coal-fired power plant, chemical pollution, Carassius auratus gibelio, Perca fluviatilis, bioaccumulation factor, trophic magnification factor, Lake Kenon

Corresponding author: Gazhit Tsybekmitova; gazhit@bk.ru

\section{Introduction}

The chemical elements are natural components of the aquatic environment, but their levels can be increased due to emissions and discharge from the coal-fired power industry. These sources of pollution can affect the quality and quantity of fish stocks. Many researchers reported the environmental impact of coal power (Kolker et al. 2006, McConnell, Edwards 2008, Czarnowska,
Frangopoulos 2012, Sikhynbaeva et al. 2014, Chanchal et al. 2016, Zholobova et al., 2016, Huang et al. 2017). In particular, Sikhynbaeva et al. (2014) noted that with a plant capacity of 1 million $\mathrm{kW}, 50 \mathrm{mln} \mathrm{m}^{3}$ of wastewater enriched with 52 tons of sulfuric acid, 26 tons of chlorides, 41 tons of phosphates, 500 tons of suspended solids and 360 tons of ash stored in dumps go to waste. Huang et al. (2017) found that the soils around the coal-fired power plant are contaminated

\section{sciendo}


with $\mathrm{Cd}, \mathrm{Hg}$, As, $\mathrm{Cu}$ and $\mathrm{Cr}$. Under these conditions, it is essential to assess and predict all possible changes in water ecosystems under external and internal factors - flows of matter and energy and assessment of optimum conditions use of ecosystems (Alimov 2000, Scheffer and Van Nes 2007, Alimov et al. 2013). Even relatively low contents of chemical elements in water and soils are bioactive and can be accumulated in fishes (Nikanorov, Zhulidov 1991, Sani 2011, Afshan et al. 2014, Hashim et al. 2014, Nzeve et al. 2014) and result in various physiological changes and deformations in their anatomical and morphological structures, including genetic defects (Ayllon, Garcia-Vazquez 2000, Jezierska, Witeska 2001, Vosylienè, Jankaitè 2006, Ergene et al. 2007, Vinodhini, Narayanan 2009, Afshan et. al. 2014, Pandey, Madhuri 2014, Gorlacheva, Afonin 2017, Mataphonov, Shoydokov 2020). Within this framework, the data on chemical element contamination of the ichthyofauna of Lake Kenon, employed for recreation and industrial fishing, are not available. From 2012 to 2016, we studied the migration of chemical pollutions in living organisms (plankton, benthos, vegetation and fishes) as well as the distribution of metals in the water systems - in the aquatic environment and in the effluent of ash dump - which fell into Lake Kenon. We assumed that chemical substances transferred to the lake with filtration water from the ash dump and wastewaters from the thermal power station No. 1 (TPP-1) are concentrated in water and the bottom deposits and represent a potential source of secondary pollution for the ecosystem.

In this study, we cover the concentrations of $\mathrm{Cr}, \mathrm{Mn}, \mathrm{Cu}, \mathrm{Zn}, \mathrm{Hg}$ and $\mathrm{Pb}$ in the fish of Lake Kenon and possible reasons for their accumulation. Being included in a human diet, the muscle tissue of fishes was used as a biological indicator of ecosystem contamination. The feed preferences of the hydrobionts were thoroughly analysed as the source of chemical pollution exposure and determination of the ecological niche of fish. The findings will help to explain the path of potential pollution of fish with chemical substances and implement management decisions on the recovery of the ecosystem of Lake Kenon.

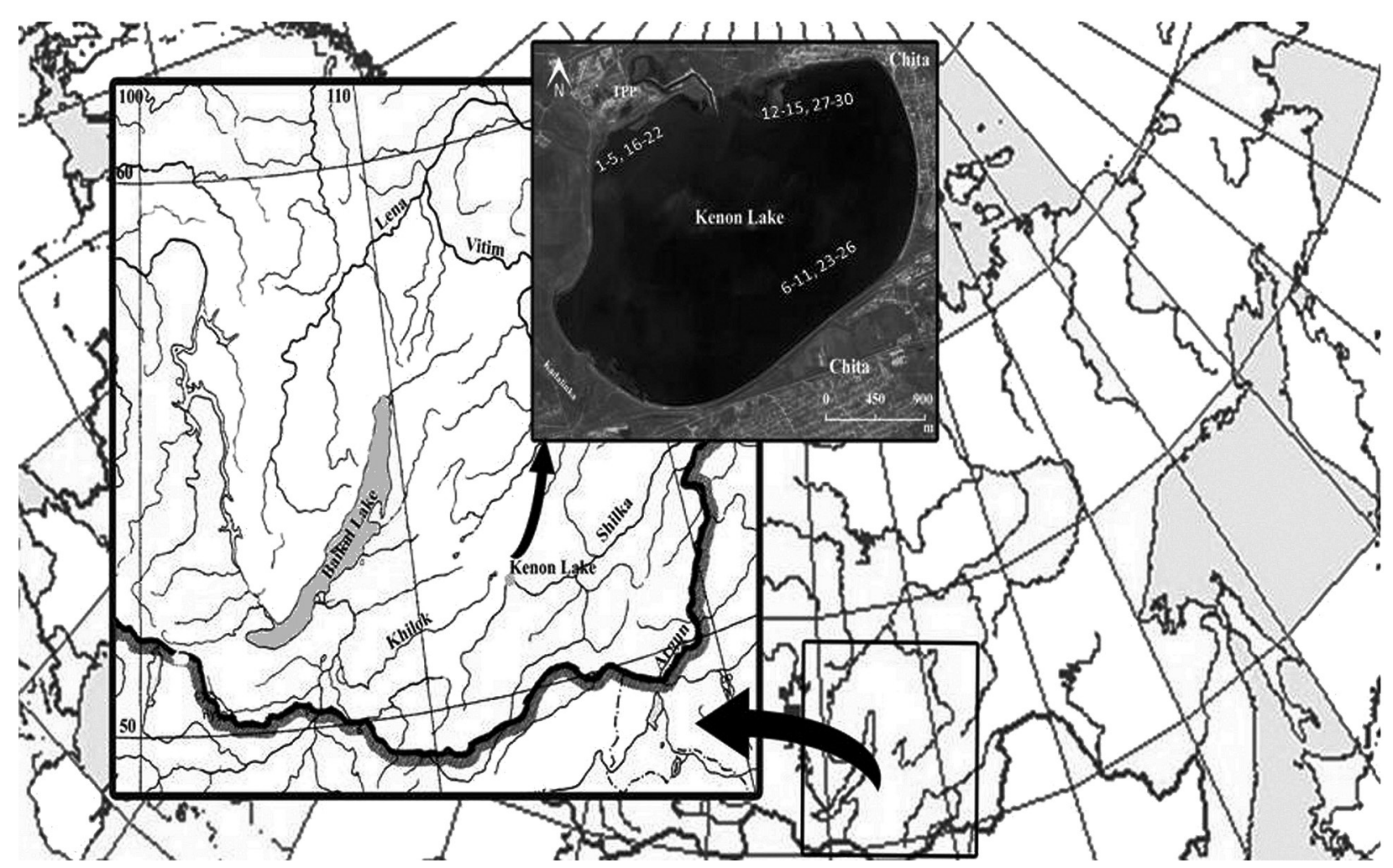

Fig. 1. Study area and stations where samples were collected.

I - Perca fluviatus (1-15: 1-5 - material selected at the TPP station; 6-11 - materials selected at the Neftebaza station; 12-15 - materials selected at the KSK station); II - Carassius auratus gibelio (16-30: 16-22 - materials selected at the TPP station; 23-26 - materials selected at the Neftebaza station; 27-30 - materials selected at the KSK station). 


\section{Materials and methods}

\section{Sampling site}

Lake Kenon is situated in the limits of the city of Chita, Transbaikal Territory, and located at latitude $52^{\circ} 04.362^{\prime} \mathrm{N}$ and longitude $113^{\circ} 21.432^{\prime} \mathrm{E}$ at an altitude of $653 \mathrm{~m}$ a.s.l. (Fig. 1). The catchment area of the lake is $227 \mathrm{~km}^{2}$, the surface area is $16 \mathrm{~km}^{2}$, the average depth is $4.4 \mathrm{~m}$, the largest depth is $5.2 \mathrm{~m}$, the length is $5.7 \mathrm{~km}$, the average width is $2.8 \mathrm{~km}$ and the shoreline length is $17.4 \mathrm{~km}$ (Itigilova et al. 1998). Lake Kenon is a natural lake of the Amur River basin. Lake Kenon is used as a cooling pond for TPP-1 since 1965. Some abiotic indicators of Lake Kenon are shown in Figure 2. According to these data, Lake Kenon is a freshwater body with an average level of salinity (TDS $\left.=548 \pm 25.1 \mathrm{mg} \mathrm{L}^{-1}\right) \cdot \mathrm{pH}$ values indicate alkaline conditions and with a sufficient amount of dissolved oxygen. Hydrocarbonate composition of surface and underground waters is typical for these zonal and climatic conditions (Zamana et al. 1998, Zhuldybina 2010, Zamana et al. 2011). The hydrochemical composition of lake waters from a two-component - sodium hydrogen

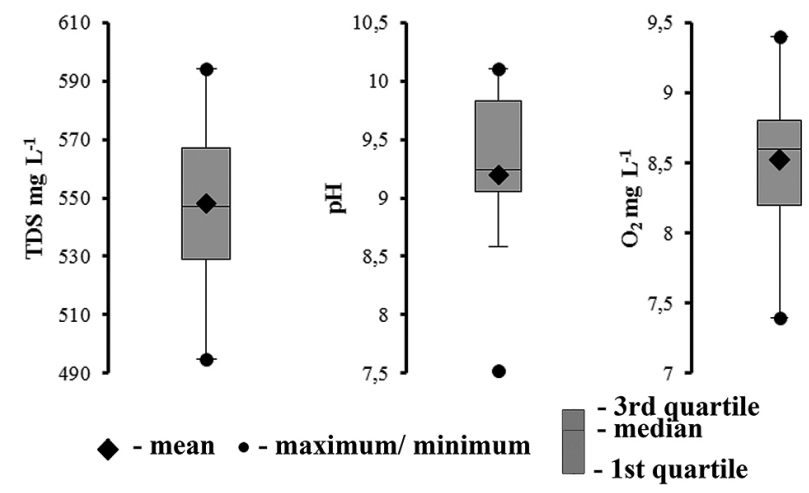

Fig. 2. Box plots depicting the selected parameters of water quality in Lake Kenon. carbonate until the 60 s of the last century was transformed into a three-component - sulfate-hydrocarbonate-chloride sodium-calcium-magnesium (Tsybekmitova 2016, Usmanova et al. 2018) (Table 1). The water composition change was due to the ash dump leakage. Approximately, 2.2-2.4 thousand tons of sulphates enter the lake annually (Zhuldybina 2010).

\section{Ichthyologic material}

In the present report, we investigate species dominant in the fish community of Lake Kenon Carassius auratus gibelio (Bloch 1782) and Perca fluviatilis (Linnaeus 1758). The long-continued catch rate for these fishes averaged not less than $80 \%$ of the total catch. Samples of fish were collected during field investigations performed from 2014 to 2016 using set nets within $3 \mathrm{~h}$ of fishery operation. Fish catch areas are shown in Figure 1. Table 2 represents particular characteristics of the selected species of both genders without conspicuous morphological changes. Fish are the final link in the food chain in the water ecosystem. We took this into account for the study of the migration of chemical elements along the trophic chain. Therefore, a preliminary analysis of food components of the fishes was carried out, and it was established what each species under study to food upon on the day of sampling. We used these data to construct diagrams of food chains. Given the fact that the fish in Lake Kenon is used in human nutrition, considerable attention has been paid to the study of the accumulation of chemical elements in the muscles of fish.

\section{Preparation of samples and analysis}

Immediately after collection, fish samples were put in a clean polythene bag to transport the fish

Table 1. Dominant ions of water $\left(\mathrm{mg} / \mathrm{L}^{-1}\right)$ in Lake Kenon in years 2000-2018.

\begin{tabular}{|l|c|c|c|c|c|c|c|c|}
\hline Parameter & $\mathrm{Na}^{+}$ & $\mathrm{K}^{+}$ & $\mathrm{Mg}^{2+}$ & $\mathrm{Ca}^{2+}$ & $\mathrm{HCO}_{3}^{-}$ & $\mathrm{SO}_{4}^{2-}$ & $\mathrm{Cl}^{-}$ & $\mathrm{TDS}$ \\
\hline Minimum & 49.3 & 2.1 & 36.8 & 48.1 & 93 & 196.9 & 68.1 & 495 \\
\hline Mean & $54.4 \pm 12.0$ & $2.2 \pm 0.1$ & $42.5 \pm 9.6$ & $55.0 \pm 14.2$ & $131.8 \pm 49.5$ & $225.2 \pm 87.8$ & $55.0 \pm 12.1$ & $548 \pm 64.4$ \\
\hline Maximum & 60.2 & 2.2 & 47.2 & 64.8 & 164.7 & 239.2 & 33.1 & 594 \\
\hline
\end{tabular}

Table 2. Selected morphometrical and biological characteristics of the fishes collected in Lake Kenon.

\begin{tabular}{|c|c|c|c|c|c|}
\hline \multirow{2}{*}{ Species } & Weight range (mean) & Length range (mean) & Age & \multirow{2}{*}{$\begin{array}{l}\text { Number of } \\
\text { individuals }\end{array}$} & \multirow{2}{*}{$\begin{array}{l}\text { Male / } \\
\text { Female }\end{array}$} \\
\hline & {$[\mathrm{g}]$} & {$[\mathrm{cm}]$} & [years] & & \\
\hline Carassius auratus gibelio & $76-246(169)$ & $13-19(16)$ & $4+-5+$ & 15 & $5 \hat{\jmath} / 10$ 우 \\
\hline Perca fluviatilis & $44-100(73)$ & 13-18 (15) & $3+-4+$ & 15 & $6 \hat{0} / 9+$ \\
\hline
\end{tabular}


Table 3. Results of analysis $\left(\mu \mathrm{g} \mathrm{g}^{-1}\right)$ of standard reference material (BOk-2) in comparison with certified values.

\begin{tabular}{|c|c|c|c|c|}
\hline $\begin{array}{c}\text { Metal } \\
{[n=6]}\end{array}$ & $\begin{array}{c}\text { Limit } \\
\text { of quantification }\end{array}$ & $\begin{array}{c}\text { SRM, Baikal perch } \\
\text { tissue, BOk-2 }\end{array}$ & $\begin{array}{c}\text { Measured } \\
\text { BOk-2 }\end{array}$ & Recovery [\%] \\
\hline $\mathrm{Cr}$ & 5.100 & $0.80 \pm 0.1$ & 0.29 & 36 \\
\hline $\mathrm{Mn}$ & 0.050 & $1.70 \pm 0.3$ & 2.10 & 123 \\
\hline $\mathrm{Cu}$ & 0.040 & $1.90 \pm 0.3$ & 1.10 & 100 \\
\hline $\mathrm{Zn}$ & 0.070 & $23.00 \pm 2.0$ & 23.00 & 78 \\
\hline $\mathrm{Hg}$ & 0.160 & $0.50 \pm 0.2$ & 0.39 & 70 \\
\hline $\mathrm{Pb}$ & 0.012 & $0.37 \pm 0.1$ & 0.26 & \\
\hline
\end{tabular}

samples to the laboratory of the Institute. In the laboratory, captured ichthyologic material was immediately analysed: each fish sample under study was identified to species and their lengths and weights were measured. Afterwards, the ages of the fishes were determined by interpreting sampled scales. The samples of fish muscle and food components were washed with distilled water and were cut into small pieces $(2-3 \mathrm{~cm})$, were then airdried to remove the extra water and were then oven-dried until the constant weight was obtained. Samples were subsequently sent to the laboratory of the Institute of Microelectronics Technology and High-Purity Materials of the Russian Academy of Sciences (Chernogolovka, Moscow, Russia). Chemical elements in samples were determined by atomic emission spectrometry (iCAP-6500, Thermo Scientific, USA) and mass spectrometry (X-7, Thermo Elemental, USA). All samples were analysed for the presence of $\mathrm{Cr}, \mathrm{Mn}, \mathrm{Cu}, \mathrm{Zn}, \mathrm{Pb}$ and total $\mathrm{Hg}$. These chemical elements are of the greatest concern in toxicology (Spry, Wiener 1991, Pandey, Madhuri 2014), although Cr, Mn, Cu and Zn are essential for normal physiological processes (Heath 2002). The accuracy of the analytical procedure was checked by the analyses of certified reference materials: for water - Certified Reference Material "Trace Metals in Drinking Water"; for bottom sediments - Certified Reference Material No. 521-84П "SGD-1A", Essexite; for fish material - muscle tissue of Perca fluviatilis (Linnaeus, 1758) from Lake Baikal (SRM, Baikal perch tissue, BOk2, registration number COOMET CRM 0068-2009$\mathrm{Ru})$. The results of the analysis of standard reference materials (BOk-2) and certified values of the elements are depicted in Table 3.

\section{Assessment of the degree of the chemical contamination}

We used two factors to evaluate the chemical element concentrations in fish: the bioaccumulation factor (BAF) and the trophic magnification factor (TMF). The chemical element concentration was compared with the maximum permissible limits (RF) and EPA (US) standards. BAF was used to evaluate the chemical element concentrations in fish tissues and was calculated as the ratio of the concentration of pollutant (chemical elements) accumulated in the tissue of organism with respect to the concentration of chemical elements in surrounding water using the following formula (Jezierska, Witeska 2001, Van der Oost et al. 2003):

$$
\mathrm{BAF}=\mathrm{C}_{\text {fish }} / \mathrm{C}_{\text {water }}
$$

where:

- $\mathrm{C}_{\text {fish }}$ is the concentration of chemical elements in fish tissue $\mathrm{mg} \mathrm{kg}^{-1}$,

- $\mathrm{C}_{\text {water }}$ is the concentration of chemical elements in surrounding water $\left(\mathrm{mg} \mathrm{L}^{-1}\right)$.

If $\mathrm{BAF}$ is greater than or equal to 1 , biological objects tend to accumulate metals.

As consumption and accumulation of a greater part of chemical elements in fish mainly result from feeding, we analysed the level of metal in the stomach content (food components). We calculated TMF to interpret the results of chemical element accumulation in trophic levels of the ecosystem. TMF reveals the relationship between the chemical element concentration in predator and the chemical element concentration in prey . The equation is as follows (Dobrovolsky 2003):

$$
\mathrm{TMF}=\mathrm{C}_{\text {predator }} / \mathrm{C}_{\text {prey }}
$$

where:

- $\mathrm{C}_{\text {predator }}$ is the concentration level of chemical elements in the organism or organ of predator,

- $C_{\text {prey }}$ is the concentration level of chemical elements in the organism of prey.

The findings on chemical elements content in fish tissues were analysed with Microsoft Excel 2010 and STATISTICA 10 for Windows (Copyright 
(C) StatSoft, Inc). The statistical significance was set at $p<0.05$. Principal component analysis (PCA) was used to perform statistical treatment of the data and to reveal the most common patterns of the relationships between the particular species and the elements accumulated in different tissues. Normalised data were obtained by dividing the observed values by the root-mean-square deviation (Shipunov et al. 2014).

\section{Results}

\section{Conditions of the aquatic environment and bottom sediments}

Previous studies showed that the ash dump leakage, rich in $\mathrm{S}, \mathrm{Cr}, \mathrm{Mn}, \mathrm{Cu}, \mathrm{Zn}, \mathrm{Hg}$ and $\mathrm{Pb}$, flows into Lake Kenon (Tsybekmitova 2016). Table 4 shows the contents of chemical elements in the aquatic environment. Our investigation revealed that water contained low concentrations of the studied metals. With the exception of copper, the trace metal concentrations in water did not exceed EPA, but $\mathrm{Cr}$ and $\mathrm{Hg}$ were compared to national standard MPL (Table 4). The contents of the other chemical elements fell below MPL and varied (mg L ${ }^{-1}$ ): $\mathrm{Cr}$ (from 0.7 to 1.5), $\mathrm{Mn}$ (from 2.3 to 6.8), $\mathrm{Zn}$ (from 1.6 to 4.0 ) and $\mathrm{Pb}$ (from 0.29 to 2.6). The comparison of received mass concentrations of chemical elements with Clark's value for sedimentary rocks revealed that bottom sediments in Lake Kenon contained low concentrations of the studied metals (Table 4).

\section{Food components of the fishes}

The feed preferences of the dominant fishes in Lake Kenon are shown in Figure 3. P. fluviatus mostly inhabit the littoral area of the lake with abundant vegetation. Being a benthophagous fish, it can occupy the trophic level of predators. The greater part of its ration during the period of
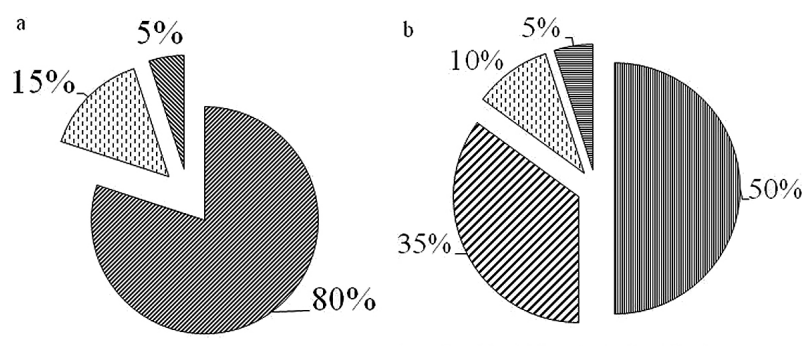

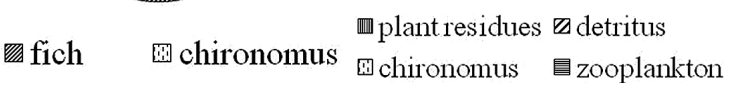

Fig. 3. The feed preferences of the dominant fishes of Lake Kenon.

a - P. fluviatus; b - C. auratus gibelio.

Table 4. The concentrations of chemical elements in the aquatic environment, bottom sediments, and food organisms of the fishes in Lake Kenon.

\begin{tabular}{|c|c|c|c|c|c|c|c|}
\hline Components & Unit & $\mathrm{Cr}$ & Mn & $\mathrm{Cu}$ & $\mathrm{Zn}$ & $\mathrm{Hg}$ & $\mathrm{Pb}$ \\
\hline \multicolumn{8}{|c|}{ Water } \\
\hline \multirow[t]{2}{*}{$\mathrm{n}=20$} & $\mu \mathrm{g} \mathrm{L}^{-1}$ & 1 & 4.00 & 0.86 & 2.70 & 0.18 & 0.16 \\
\hline & SD & 0 & 1.78 & 0.11 & 1.04 & 0.08 & 0.07 \\
\hline MPL & $\mu \mathrm{g} \mathrm{L}^{-1}$ & 1 & 10.00 & 5.00 & 10.00 & 0.10 & 6.00 \\
\hline EPA & $\mu \mathrm{g} \mathrm{L}^{-1}$ & 50 & 50.00 & 1.00 & 5.00 & 2.00 & 50.00 \\
\hline \multicolumn{8}{|c|}{ Bottom sediments } \\
\hline \multirow[t]{2}{*}{ damp $70 \%, n=25$} & $\mu \mathrm{g} \mathrm{kg}^{-1}$ & 13874 & 33 & 24535 & 43243 & 25 & 12072 \\
\hline & SD & 2114 & 10 & 3351 & 3694 & 20 & 2375 \\
\hline $\mathrm{C}_{\text {crust }}$ & $\mu \mathrm{g} \mathrm{kg}^{-1}$ & 100000 & 900000 & 55000 & 70000 & 70 & 14000 \\
\hline \multicolumn{8}{|c|}{ The food organisms from the stomach of the fish } \\
\hline \multirow[t]{2}{*}{ Chara sp. $\mathrm{n}=10$} & $\mu \mathrm{g} \mathrm{kg}^{-1}$ & 200 & 170563 & 1066 & 3488 & 5 & 320 \\
\hline & SD & 94 & 1232 & 255 & 1144 & 2 & 81 \\
\hline \multirow[t]{2}{*}{ Amphipods, $\mathrm{n}=7$} & $\mu \mathrm{g} \mathrm{kg}^{-1}$ & 86 & 4920 & 9970 & 10400 & 16 & 70 \\
\hline & SD & 15 & 303 & 117 & 1130 & 8 & 16 \\
\hline \multirow[t]{2}{*}{ Chironomus spp., $\mathrm{n}=7$} & $\mu \mathrm{g} \mathrm{kg}^{-1}$ & 500 & 23500 & 3570 & 14900 & 7 & 464 \\
\hline & SD & 30 & 1810 & 160 & 5200 & 1 & 20 \\
\hline DL, biota & $\mu \mathrm{g} \mathrm{kg}^{-1}$ & 20 & 50 & 40 & 70 & 4 & 10 \\
\hline
\end{tabular}

SD - standard deviation, MPL - the maximum permissible limits (approved by the Order of Federal Fishery Agency of the RF No. 20 as of January 18, 2010), EPA - Environmental Protection Agency (EPA 2002), C crust - elements clarke in the Earth's crust (Kabata-Pendias and Mukherjee 2007), DL - the detection limit of the method. 
our research consisted of fish larvae $(80 \%)$. C. auratus gibelio is a benthic species mainly feeding on plant remnants (charophytes) and detritus (sums up to $85 \%$ ). The concentrations of chemical elements in the food components of the examined fishes are represented in Table 4. Chromium, magnesium and lead levels in Chironomus spp. and Chara sp. were higher than in amphipods. Copper and mercury levels were higher in amphipods than in other organisms. The amphipods too have a high level of mercury.

\section{Chemical elements distribution in fish muscles and food components of the fish stomach}

The concentrations of heavy metals in muscles and food bolus are shown in Table 5 . In the muscles of $P$. fluviatus and C. auratus gibelio, the contents of chemical elements in descending order are as follows: $\mathrm{Zn}>\mathrm{Cu}>\mathrm{Mn}>\mathrm{Pb}>\mathrm{Hg}>\mathrm{Cr}$. In the muscles of $P$. fluviatus, the contents of $\mathrm{Mn}, \mathrm{Cu}$ and $\mathrm{Zn}$ are insignificant as compared to the level of chemical elements in food components. The concentrations of $\mathrm{Mn}$ and $\mathrm{Pb}$ in the muscles researched fish species are close to the MPL but higher than the EPA requirements, and the $\mathrm{Hg}$ concentration exceeds the MPL. In the muscles of $C$. auratus gibelio, the contents of Mn and $\mathrm{Hg}$ correspond to MPL, but higher than the EPA requirements, whereas the level of $\mathrm{Zn}$ is much higher than MPL and EPA. The concentrations of $\mathrm{Cr}, \mathrm{Cu}$ and $\mathrm{Pb}$ fell below MPL. Higher contents of chemical elements in C. auratus gibelio are due to its benthic habitat, and there was total accumulation of chemicals from water, bottom sediments and consumed food. High levels of metal in the stomach content of the fishes were detected in the following descending order: in P. fluviatus $-\mathrm{Mn}>\mathrm{Zn}>\mathrm{Cu}>\mathrm{Hg}>\mathrm{Pb}>\mathrm{Cr}$; in C. auratus gibelio $-\mathrm{Zn}>\mathrm{Mn}>\mathrm{Cu}>\mathrm{Cr}>\mathrm{Pb}>\mathrm{Hg}$.

\section{Bioaccumulation factor and trophic magnification factor in the ecosystem of Lake Kenon}

The levels of chemical elements in the water, bottom sediments and food organisms from the stomach in dominant fishes are shown in Table 4. BAF and TMF for the fishes were calculated from those values (Figs 4 and 5). BAFs of chemical elements accumulated from the surrounding water for $P$. fluviatus in descending order are as follows: $\mathrm{Zn}>\mathrm{Pb}>\mathrm{Hg}>\mathrm{Cu}$ (Fig. 4). P. fluviatus accumulates $\mathrm{Hg}$ in equal measure from both water and bottom sediments. BAFs of chemical elements accumulated from the surrounding water for $C$. auratus gibelio in descending order are as follows: $\mathrm{Zn}>\mathrm{Pb}>\mathrm{Hg}>\mathrm{Cu}$. Manganese and mercury are accumulated in the muscles of C. auratus gibelio from bottom sediments. The factors of trophic magnification chemical

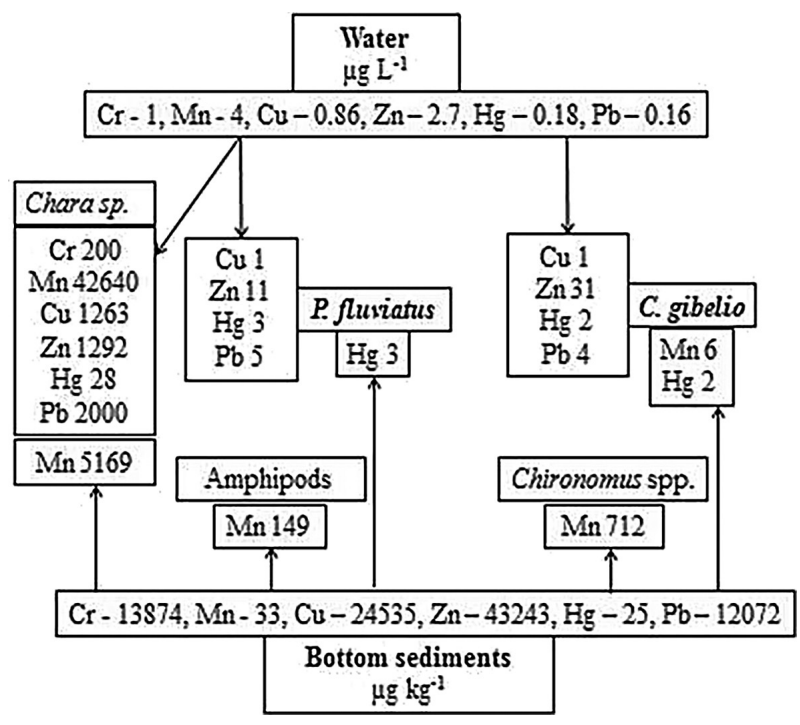

Fig. 4. Bioaccumulation factors in the ecosystem of the Lake Kenon (values - $\mathrm{n}$ times).

Table 5. Chemical elements in the fishes $(\mathrm{N}=10)$ of Lake Kenon ( $\mathrm{mg} \mathrm{kg}^{-1}$ of dry matter).

\begin{tabular}{|c|c|c|c|c|c|c|}
\hline Fish species & $\mathrm{Cr}$ & $\mathrm{Mn}$ & $\mathrm{Cu}$ & $\mathrm{Zn}$ & $\mathrm{Hg}$ & $\mathrm{Pb}$ \\
\hline \multicolumn{7}{|c|}{ In the muscles } \\
\hline P. fluviatus & $0.18 \pm 0.03$ & $0.85 \pm 0.15$ & $0.91 \pm 0.13$ & $30.8 \pm 4.36$ & $0.47 \pm 0.17$ & $0.73 \pm 0.10$ \\
\hline C. auratus gibelio & $0.23 \pm 0.06$ & $1.00 \pm 0.25$ & $1.20 \pm 0.37$ & $82.5 \pm 56.00$ & $0.27 \pm 0.11$ & $0.58 \pm 0.09$ \\
\hline MPL & 1.00 & 1.00 & 10.00 & 40.00 & 0.30 & 1.00 \\
\hline EPA & - & 0.05 & 1.00 & 5.00 & - & 0.05 \\
\hline \multicolumn{7}{|c|}{ In the food components of the fish stomach } \\
\hline P. fluviatus & $0.029 \pm 0.004$ & $277 \pm 14.5$ & $18.7 \pm 6.2$ & $179.9 \pm 54.9$ & $0.55 \pm 0.08$ & $0.19 \pm 0.06$ \\
\hline C. auratus gibelio & $13.60 \pm 4.21$ & $485 \pm 53.0$ & $80.8 \pm 14.5$ & $673.5 \pm 167.8$ & $0.45 \pm 0.01$ & $3.07 \pm 0.03$ \\
\hline
\end{tabular}




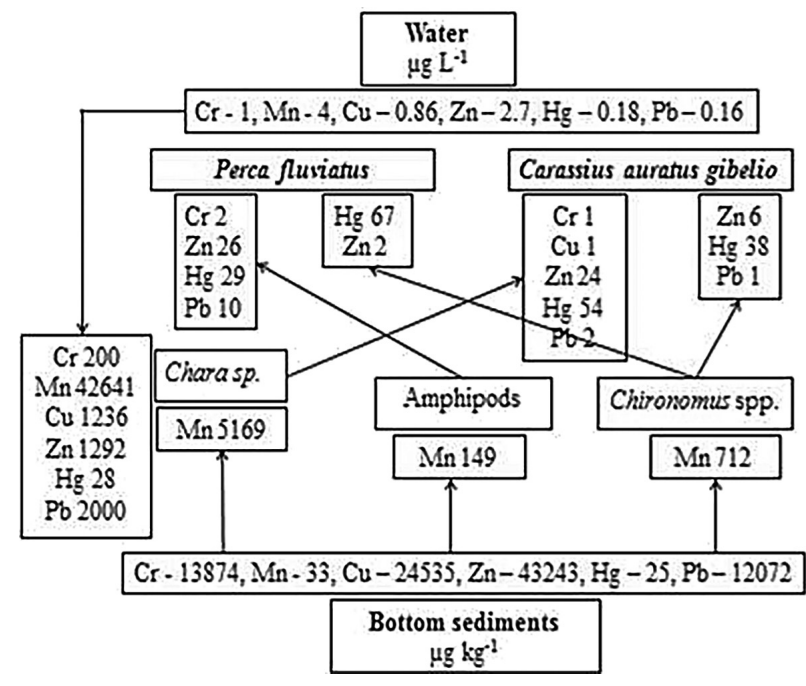

Fig. 5. Factors of trophic magnification in the ecosystem of the Lake Kenon.

elements in the hydrobints of Lake Kenon are as follows (Fig. 5): the highest accumulation ratio Zn in C. auratus gibelio from Chara sp. (24 times) and $\mathrm{Hg}$ from Chironomus spp. (38 times). The highest accumulation ratio $\mathrm{Zn}$ (26 times) and $\mathrm{Hg}$ (29 times) at $P$. fluviatus from amphipods. At the same time, $\mathrm{Hg}$ in $\mathrm{P}$. fluviatus muscles is more higher accumulated from Chironomus spp. (67 times). These results show that chemical elements enter organisms not only through the environment but also with food. For such elements as $\mathrm{Cr}$ and $\mathrm{Cu}$ in the trophic chains considered, it is not always obvious, which requires additional analysis.

\section{Principal component analysis}

Component analysis singled out two factors that totaled up to $69.84 \%$ (Fig. 6). Other factors were considered being insignificant in total variance. PCA revealed the following characteristics of the metal-species correlation. In the muscles of $P$. fluviatus, significant correlation on the principal component 1 (Axis F1) was with $\mathrm{Hg}$ $(-0.79)$ and $\mathrm{Pb}(-0.55)$; in C. auratus gibelio - with $\mathrm{Zn}$ (0.93), Cr (0.74), $\mathrm{Cu}$ (0.74) and Mn (0.62). The principal component 2 showed a significant correlation of $P$. fluviatus with $\mathrm{Pb}(-0.69)$. Thus, the PCA diffraction analysis carried out practically confirmed the obtained results of chemical pollutantion of the corresponding studied fish.

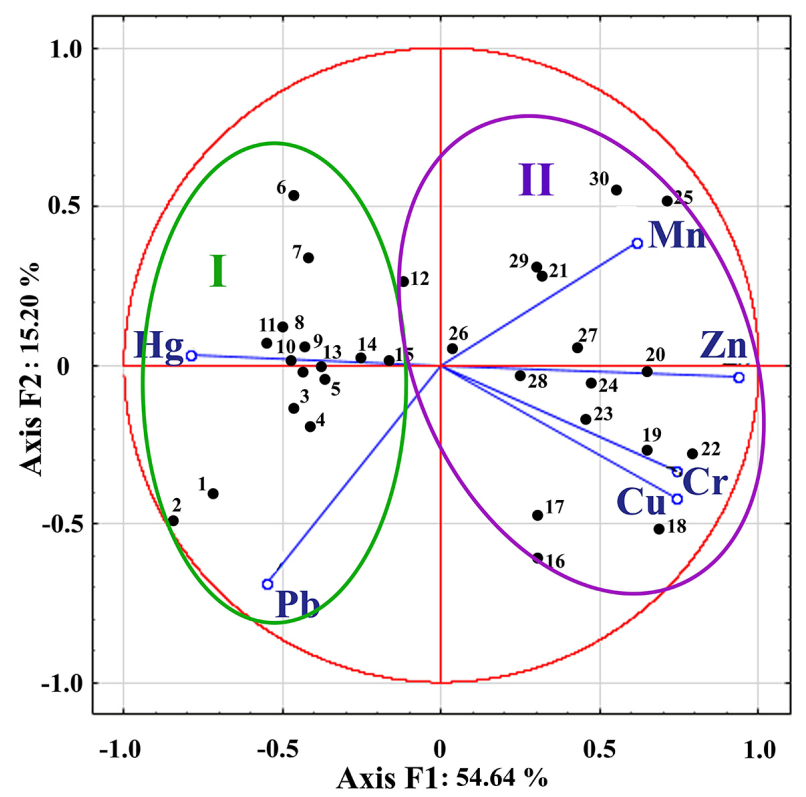

Fig. 6. Correlation of heavy metals in the muscles with fish species in the space of latent variables I - Perca fluviatus (1-15: 1-5 - samples collected at the station of the thermal power plant; 6-11 - samples collected at the station "Neftebaza"; 12-15 - samples collected at the station "KSK"); II - Carassius auratus gibelio (16-30: 16-22 - samples collected at the station of the thermal power plant; 23-26 - samples collected at the station "Neftebaza"; 27-30 - samples, collected at the station "KSK").

\section{Discussion}

The lack of advanced clean coal combustion technologies for coal-fired power plants results not only in atmospheric chemical pollution but also in the pollution of water ecosystems. Chemical pollutions change the quality of lake waters, accumulate in hydrobionts, and interfere with the biodiversity and structure of the lakes populations (Sunda, Guillard 1976, Nikanorov, Zhulidov 1991, Heaven et al. 2000, Cardwell et al. 2002, Tulonen et al. 2006, Moiseenko et al. 2005, Pastukhov 2012, Moiseenko, Gashkina 2020).

\section{Conditions of the aquatic environment and bottom sediments}

Our investigation revealed that water and bottom sediments in Lake Kenon contained low concentrations of the studied metals. Although in Lake Kenon, $\mathrm{Hg}$ exceeds the background value more than three times, which is comparable with polluted waters. The background values of 
the concentration of $\mathrm{Hg}$ in freshwater bodies of European and Caucasian Russia, and in those of the Tien Shan Mountains, were evidenced in the study by Nikanorov Zhulidov (1991) and estimated as equal to or less than $0.05 \mathrm{mg} \mathrm{L}^{-1}$. The research (Chale 2002) has shown that concentrations of trace metals of water were lower than that in fish tissues, which is consistent with our research. The self-cleaning ability from water ecosystems where aquatic organisms a purify waters polluted plays a role here (Moiseenko et al. 2005, Alimov et al. 2013). As compared to the aquatic environment, the contents of chemical elements in bottom sediments are an order of magnitude higher (Table 4). Such a high concentration in bottom sediments by the fact that metals are bound to organic compounds of plant and animal residuals settling in bottom sediments (Duan et al. 2014). Correlations between chemical elements and organic matter of bottom sediments are well traced in Lake Kenon (Tsybekmitova et al. 2019). Due to the sedimentation of suspended organic matter capable of adsorbing ions and mineral particles from water, the bottom sediments of Lake Kenon are enriched with $\mathrm{Mn}, \mathrm{Zn}, \mathrm{Hg}$ and $\mathrm{Pb}$. Bottom sediments not only function as accumulators of heavy metals but also as one of the potential sources of pollution of the chemical element ecosystem.

\section{Food components of the fish}

The feed preferences of the dominant fishes of Lake Kenon are as follows: P. fluviatus is benthophagous (Amphipods and Chironomus spp.) but can occupy the trophic level of predators. In research studies performed by Craig (1978), Dörner et al. (2003), invertebrates and age-0 fish were also the main food components of large P. fluviatus. C. auratus gibelio is a benthic species mainly feeding on plant remnants (Charophytes) and detritus (sums up to $85 \%$ ). As indicated (Szczerbowski 1996), the most frequent diet items to C. auratus gibelio include planktonic crustaceans, insect larvae, molluscs and plants. Peňaz and Kokeš (1981) reported 100 and 91.3\% of the fish from reservoirs of Sturovo and Chlaba to contain detritus in their digestive tracts. In this way, the C. auratus gibelio diet items in our study were similar in composition to those reported by other authors.

\section{Chemical elements distribution in fish muscles and food components of the fish stomach}

In such reference ecosystems as Lake Baikal, the content of $\mathrm{Cr}$ in the muscles of fishes ranges from 0.3 to $0.86 \mathrm{mg} \mathrm{kg}^{-1}$ (Vetrov et al. 1989); in the ecosystem of Lake Kennebec (Maine, USA), the level of $\mathrm{Cr}$ in the muscles of $P$. fluviatilis ranges from 0.1 to $1.7 \mathrm{mg} \mathrm{kg}^{-1}$ of dry matter (Friant et al. 1979), which was compared to our findings. Low concentration of $\mathrm{Cr}$ in the muscles of fishes is due to its higher accumulation in the systems of active metabolism (Moiseenko et al. 2005). In the fish muscles in Lake Kenon, zinc is 2-4 times higher, and $\mathrm{Cu}$ is seven times lower, and are comparable in $\mathrm{Pb}$ content to those obtained (Ebrahimpour et al. 2011, Younis et al. 2015). Hg accumulated in the muscles of $C$. auratus gibelio and P. fluviatus in Lake Kenon is higher than in Lake Chany and the Chivyrkuisky Gulf of Lake Baikal (Popov, Androsova 2008) and corresponds to the level of industrial impact on water bodies (Nyukkanov 1996, Pastukhov 2012). In the muscles of the fishes in Lake Kenon, the content of $\mathrm{Zn}$ is 2-5 times as high as in Lake Chany (Popov, Androsova 2008), which corresponds to the data of the Votkinskoye Reservoir (Gileva et al. 2014) and of the wetland ecosystem from the Lower Prut Floodplain Natural Park in Romania (David et al. 2012). Metals like Mn function as a cofactor in several enzyme systems. However, when in excessively high concentration, these bioactive metals may pose serious threats to normal metabolic processes (Bury et al. 2003). The content of manganese in the muscles of fish from Lake Kenon is lower than that presented in the work (Rahman et al. 2012), which might be due to the tendency of various species of fish to concentrate certain elements in their tissue more than the surrounding. In the food components of the fish stomach in Lake Kenon, the high concentration of $\mathrm{Zn}, \mathrm{Mn}$ and $\mathrm{Hg}$ shows that chemical contaminants enter organisms not only through the environment but also with food, which is supported by research (Wang et al. 2015). For example, it was detected that approximately $70 \%$ of methylated $\mathrm{Hg}$ is consumed with food, while only $10 \%$ is accumulated through gills (Heath 2002). 


\section{Bioaccumulation factor and trophic magnification factor in the ecosystem of Lake Kenon}

On the biogeochemical barrier, the migration of chemical elements drops drastically and their concentrations begin to rise (Alekseenko 2003). At the same time, chemical elements flowing into water ecosystems are selectively accumulated in organisms through the system of trophic interrelations. In the plant food organisms (Chara sp.), chemical elements accumulation mainly originate from the water column (Cardwell et al. 2002, Bazarova 2013). Only manganese accumulates in them from bottom sediments. The detected content of $\mathrm{Mn}$ in bottom sediments $\left(33 \mathrm{mg} \mathrm{kg}^{-1}\right.$, Table 4) is six times higher in the muscles of $C$. auratus gibelio (Fig. 4). Being transferred along the trophic chain, Mn is actively precipitated on the oxygen barrier made up by aquatic vegetation and breathing vibrations of Chironomus spp. larva (Nikanorov, Zhulidov 1991). From Chara sp. most of the chemical elements accumulate in C. auratus gibelios since is benthic species mainly feeding on plant remnants (charophytes) (Szczerbowski 1996). Also, food relations of C. auratus gibelio is connected with bottom organisms that inhabit in charophytes - with Chironomus spp. (Fig. 5). This results in higher contents of $\mathrm{Hg}, \mathrm{Cu}, \mathrm{Zn}$ in C. auratus gibelio in Lake Kenon as compared to P. fluviatus. Quantification analyses of chemical elements in fishes performed by a number of scientists (Sani 2011, Hashim et al. 2014, Nzeve et al. 2014, Moiseenko, Gashkina 2020) revealed a higher level of metals contamination in predators. The findings on the contents of chemical elements in P. fluviatus of Kenon Lake, shown as a predator, and on the contents in muscles of mercury and lead are higher than in C. auratus gibelios. The phenomenon of higher accumulation of $\mathrm{Hg}$ in predatory fishes as compared to non-predatory ones is explained by the progressive accumulation in the trophic chain typical for this metal (magnification effect) (Popov 2002, Komov et al. 2004, Popov, Androsova 2014). The food spectrum of $P$. fluviatus includes not only fishes but also bottom organisms. As it was observed, $\mathrm{Zn}$ and $\mathrm{Hg}$ in bottom sediments through amphipods and Chironomus spp. reach fishes while accumulating in them exponentially (Fig.
5). Nazyrov (2003) detected the correlation between zoobenthos (especially Chironomids larva) and bottom sediments, which contributes to the accumulation of $\mathrm{Zn}$ and $\mathrm{Hg}$. It was observed that the $\mathrm{Pb}$ enters fish through water containing high concentrations of metals (Wood et al. 2012). Consequently, high concentrations of $\mathrm{Pb}$ in the aquatic environment, $\mathrm{Pb}$ to accumulation in aquatic organisms. In Lake Kenon, $\mathrm{Pb}$ enters the body of $P$. fluviatus from benthic organisms, and into C. auratus gibelios - from Chara sp. and Chironomus spp.

\section{Conclusion}

The lack of advanced clean coal combustion technologies for coal-fired power plants results in the pollution of water ecosystems. The findings underline the complicated distribution of chemical elements in fishes due to both exogeneous and endogenous factors of the ecosystem. This study underlines the importance of monitoring the levels of chemical pollutions not only in the water column and bottom sediments but also in the hydrobionts including fish to prevent this type of contamination. In addition, management decisions for mitigation practices in Lake Kenon should be preferably focussed on the disposal of wastewater from the ash dump contaminated with chemical elements.

\section{Acknowledgements}

The study is performed within the framework of the federal research program (project № FUFR2021-0006). We appreciate the materials on benthic organisms kindly provided by P.V. Matafonov. The authors are grateful to the two reviewers for their useful comments that allowed us to improve our previous version of the manuscript.

\section{Author's contribution}

Ts.G.Ts. - 45\% - conducting research, research methodology and data analysis, preparation of the manuscript, preparation of the discussion chapter; G.E.P.- $35 \%$ - conducting research, data analysis, preparation of the manuscript, preparation of the discussion chapter; T.N.A.- $20 \%$ - software, making figures, study area description; preparation of the discussion chapter. All authors have read and agreed to the published version of the manuscript. 


\section{References}

Afshan S., Ali S., Ameen S., Farid M., Bharwana A.S., Hannan F., Ahmad R., 2014. Effect of different heavy metal pollution on fish. Research Journal of Chemical and Environmental Sciences 2(1): 35-40.

Alekseenko V.A., Alekseenko L.P., 2003. Geochemical barriers (in Russian). Logos, Moscow: 137.

Alimov A.F., 2000. On the theory of water ecosystem operation (in Russian). Nauka, St Petersburg: 147.

Alimov A.F., Bogatov V.V, Golubkov S.M., 2013. Production hydrobiology (in Russian). Nauka, St Petersburg: 339.

Ayllon F., Garcia-Vazquez E., 2000. Induction of micronuclei and other nuclear abnormalities in European minnow Phoxinus phoxinus and mollie Poecilia latipinna: An assessment of the fish micronucleus test. Mutation Research/ Genetic Toxicology and Environmental Mutagenesis 467(2): 177-186. DOI: 10.1016/S1383-5718(00)00033-4.

Bazarova B.B., 2013. Chemical element contents in charaphyta of the Lake Kenon (the Transbaikal region) (in Russian). Water: Chemistry and Ecology 11(65): 54-60.

Bury N.R., Walker P.A., Glover C.N., 2003. Nutritive metal uptake in teleost fish. Journal of Experimental Biology 206: 11-23. DOI: $10.1242 /$ jeb.00068.

Cardwell A.J., Hawker D.W., Greenway M., 2002. Metal accumulation in aquatic macrophytes from southeast Queensland, Australia. Chemosphere 48(7): 653-663. DOI: 10.1016/S0045-6535(02)00164-9.

Chale F.M.M., 2002. Trace metal concentration in water, sediments and fish tissues from Lake Tanganyika. Science of Total Environment 299(1-3): 155-161. DOI: 10.1016/s00489697(02)00252-8.

Chanchal V., Sangeeta M., Hussain A., 2016. Heavy metal contamination of groundwater due to fly ash disposal of coal-fired thermal power plant, Parichha, Jhansi, India. Cogent Engineering 3(1): 1179243. DOI: 10.1080/23311916.2016.1179243.

Craig J.F., 1978. A study of the food and feeding of perch, Perca fluviatilis L., in Windermere. Freshwater Biology 8: 59-68. DOI: 10.1111/j.1365-2427.1978.tb01426.x.

Czarnowska L., Frangopoulos C.A., 2012. Dispersion of pollutants, environmental externalities due to a pulverized coal power plant and their effect on the cost of electricity. Energy 41(1): 212-219. DOI: 10.1016/j.energy.2011.08.004.

David I.G., Matache M.L., Tudorache A., Chisamera G., Rozylowicz L., Radu G.L., 2012. Food chain biomagnification of heavy metals in samples from the lower Prut floodplain natural park. Environmental Engineering and Management Journal 11(1): 69-73.

Dobrovolsky V.V., 2003. Fundamentals of biogeochemistry. Publishing Center "Academy", Moscow: 400.

Dörner H., Berg S., Jacobsen L., Hülsmann S., Brojerg M., Wagner A., 2003. The feeding behaviour of large perch Perca fluviatilis (L.) in relation to food availability: A comparative study. Hydrobiologia 506(1-3): 427-434. DOI: 10.1023/B:HYDR.0000008608.22869.99.

Duan D., Ran Y., Cheng H., Chen J., Wan G., 2014. Contamination trends of trace metals and coupling with algal productivity in sediment cores in Pearl River Delta, South China. Chemosphere 103: 35-43. DOI: 10.1016/j. chemosphere.2013.11.011.

Ebrahimpour M., Pourkhabbaz A., Baramaki R. et al., 2011. Bioaccumulation of heavy metals in freshwater fish species, Anzali, Iran. Bulletin of Environmental Contamination and Toxicology 87(4): 386-392. DOI: 10.1007/s00128-0110376-y.
EPA (Environmental Protection Agency), 2002. Quality Criteria for Water. Washington, 440(9): 76-123. Online: www. epa.gov/sdwa/drinking-water-regulations-and-contaminants (accessed 23 December 2020).

Ergene S., Cavaş T.,Celik A., Köleli N., Kaya F., Karahan A., 2007. Monitoring of nuclear abnormalities in peripheral erythrocytes of three fish species from the Goksu Delta (Turkey): Genotoxic damage in relation to water pollution. Ecotoxicology 16(4): 385-391. DOI: 10.1007/s10646007-0142-4.

Friant S.L., 1979. Trace metal concentrations in selected biological, sediment and water column samples in a northern New England river. Water, Air and Soil Pollution. 11: 455-465. DOI: 10.1007/BF00283437.

Gileva T.A., Zinivjev E.A., Kostitsyna N.V., 2014. Heavy metals content in organs and tissues of fish inhabiting different type reservoirs of the Perm Region (in Russian). Agrarian Bulletin of the Urals 8(126): 73-77.

Gorlacheva E.P., Afonin A.V., 2017. Silver Crucian Carp Carassius Auratus Gibelio (Bloch, 1782) as an indicator of ecosystem health in Lake Kenon (in Russian). Scholarly Notes of Transbaikal State University 12(1): 6-12.

Hashim R., Song T.H., Muslim N.Z.M., Yen T.P., 2014. Determination of heavy metal levels in fishes from the lower reach of the Kelantan River, Kelantan, Malaysia. Tropical Life Sciences Research 25(2): 21-39.

Heath A.G., 2002. Water Pollution and Fish Physiology. Lewis Publishers: Boca Raton, Florida.

Heaven S., Ilyushenko M.A., Tanton T.W., Ullrich S.M., Yanin E.P., 2000. Mercury in the River Nura and its floodplain, Central Kazakhstan: I. River sediments and water. Science of the Total Environment 260(1-3): 35-44. DOI: 10.1016/S0048-9697(00)00540-4.

Huang X., Hu J., Qin F., Quan W., Cao R., Fan M., Wu X., 2017. Heavy metal pollution and ecological assessment around the Jinsha coal-fired power plant (China). International Journal of Environmental Research and Public Health 14(12): 1589. DOI: 10.3390/ijerph14121589.

Itigilova M.Ts., Chechel A.P., Zamana L.V. et al., 1998. Ecology of an inner-city water body (in Russian). Publishing House SB RAS, Novosibirsk: 237.

Jezierska B., Witeska M., 2001. Summary of metal-induced disturbances in fish organism. In: Metal Toxicity to Fish. Wydawnictvo Akademii Podlaskej, Siedlce: 214-243.

Kabata-Pendias A., Mukherjee A.B., 2007. Trace elements from soil to human. Springer, Berlin: 550 .

Kolker A., Senior C.L., Quick J.C., 2006. Mercury in coal and the impact of coal quality on mercury emissions from combustion systems. Applied Geochemistry 21(11): 18211836. DOI: 10.1016/j.apgeochem.2006.08.001.

Komov V.T., Stepanova I.K., Gremyachikh V.A., 2004. Mercury content in fish muscles from water bodies of the North-West of Russia: Causes of intensive accumulation and assessment of the negative effect on human health. In: B.A.Flerov (ed), Actual problems of aquatic toxicology. IBI RAS, Borok: 99-123.

Mataphonov P.V., Shoydokov A.B., 2020. Toxic pollution assessment of Chita TPP-1 cooling reservoir by applying the method of head capsule morphological deformations in Chironomid larvae. Amurian Zoological Journal 12(2): 201-210. DOI: 10.33910/2686-9519-2020-12-2-201-210.

McConnell J.R., Edwards R., 2008. Coal burning leaves toxic heavy metal legacy in the Arctic. PNAS 105(34): 1214012144. DOI: $10.1073 /$ pnas.0803564105.

Moiseenko T.I., Kudryavtseva L.P., Gashkina N.A., 2005. Assessment of the geochemical background and anthropo- 
genic load by bioaccumulation of microelements in fish. Water Resources 32:640-652. DOI: 10.1007/s11268-0050081-5.

Moiseenko T.I., Gashkina N.A., 2020. Distribution and bioaccumulation of heavy metals $(\mathrm{Hg}, \mathrm{Cd}$ and $\mathrm{Pb})$ in fish: Influence of the aquatic environment and climate. Environmental Research Letters 15: 115013. DOI: 10.1088/17489326/abbf7c.

Nazyrov A.D., 2003. Biaccumulation of heavy metalls, dioxins and influence on hematological and biochemical indicators of hydrobionts river Ufa (in Russian). Abstract of the dissertation. Academic Press, Ufa.

Nikanorov A.M., Zhulidov A.V., 1991. Biomonitoring of metals in freshwater ecosystems. Gidrometeoizdat, Leningrad: 310.

Nyukkanov A.N., 1996. The content of mercury compounds, lead and cadmium in fish from freshwater waterbody Yakutia. Abstract of the dissertation. RRIVM, Pokrov: 22. Online: https://dlib.rsl.ru/01000330389 (accessed 20 Desember 2019).

Nzeve J.K., Njuguna S.G., Kitur E.C., 2014. Bioaccumulation of heavy metals in Clarias gariepinus and Oreochromis spirulus Niger from Masinga Reservoir, Kenya. IOSR Journal of Environmental Science, Toxicology and Food Technology 8(10): 58-63.

Pandey G., Madhuri S., 2014. Heavy metals causing toxicity in animals and fishes. Research Journal of Animal, Veterinary and Fishery Sciences 2(2): 17-23.

Pastukhov M.V., 2012. Ecological aspects of mercury accumulation by hydrobionts of the Baikal-Angarsk water system. Online: static.freereferats.ru/_avtoreferats/01005484084. pdf (accessed 10 February 2019).

Peňaz M., Kokeš J., 1981. Notes on the diet, growth and reproduction of Carassius auratus gibelio in two localities in southern Slovakia. Folia Zoologica 30(1), 83-94.

Popov P.A., 2002. Assessment of the ecological status of water bodies using ichthyoindication methods. Novosibirsk National Research State University Press, Novosibirsk: 270.

Popov P.A., Androsova N.V., 2008. Indication of the ecological state of water bodies of Siberia from the content of heavy metals in fishes. Geography and Natural Resources 3: 36-41.

Popov P.A, Androsova N.V., 2014. Metal content in the muscular tissue of fish the Ob River. Tomsk State University Journal of Biology 4(28): 108-122. DOI: 10.17223/19988591/28/7.

Rahman M.S., Molla A.H., Saha N., Rahman A., 2012. Study on heavy metals levels and its risk assessment in some edible fishes from Bangshi River, Savar, Dhaka, Bangladesh. Food Chemistry 134:1847-1854.

Sani U., 2011. Determination of some heavy metals concentration in the tissues of Tilapia and Catfishes. Biokemistri. 23(2): 73-80.

Shipunov A.B., Baldin E.M., Volkova P.A., Korobeinikov A.I., Nazarova S.A., Petrov S.V., Sufiyanov V.G., 2014. Visual statistics, we use R! (in Russian) DMK Press, Moscow.

Scheffer M., van Nes E.H., 2007. Shallow lakes theory revisited: various alternative regimes driven by climate, nutrients, depth and lake size. In: Gulati R.D., Lammens E., De Pauw N., Van Donk E. (eds) Shallow Lakes in a Changing World. Developments in Hydrobiology, vol 196. Springer, Dordrecht. https://doi.org/10.1007/978-1-40206399-2_41.

Sikhynbaeva J.S., Shakirov B.S., Zholdasbekova K.A., Ashitova N.Zh., 2014. Some questions about the impact of energy on the environment. International Journal of Sciences: Basic and Applied Research 3(2): 89-90.
Spry D.J., Wiener T.G., 1991. Metal bioavailability and toxicity to fish from low-alkalinity lakes: A critical review. Environmental Pollution 71(2-4): 243-304. DOI: 10.1016/0269-7491(91)90034-T.

Sunda W.G., Guillard R.R.L., 1976. The relationship between cupric ion activity and the toxicity of copper to phytoplankton. Journal of Marine Research 34: 511-529.

Szczerbowski J.A., Szczerbowski A., 1996. Karasie [The genus Carassius]. IRŚ, Olsztyn, 45-88.

Tsybekmitova G.Ts., 2016. Filtration water quality of ash dump TPP-1 and possible ways of their stream into the Kenon Lake (Zabaikalsky Krai) (in Russian). Water: Chemistry and Ecology 2: 11-17.

Tsybekmitova G.Ts., Kuklin A.P., Tsyganok V.I., 2019. Heavy metals in bottom sediments of Lake Kenon (The Trans-Baikal Territory, Russia). Bulletin of Environmental Contamination and Toxicology 103: 286-291. DOI: 10.1007/ s00128-019-02645-7.

Tulonen T., Pihlström M., Arvola L., Rask M., 2006. Concentrations of heavy metals in food web components of small, boreal lakes. Boreal Environment Research 11: 185194. DOI: 10.12691/jephh-1-1-1.

Usmanova L.I., Zamana L.V., Usmanov M.T., 2018. Geochemistry of underground and surface water in the zone of influence of the ash daump of Chita TPP-1. International Research Journal 11(77): 91-95. DOI: 10.31554/9785-7925-0536-0-2018-379-382.

Van der Oost R., Beyer J., Vermeulen N.P.E., 2003. Fish bioaccumulation and biomarkers in environmental risk assessment: a review. Environmental Toxicology and Pharmacology 13: 57-149. DOI: 10.1016/S1382-6689(02)00126-6.

Vetrov V.A., Kornakova E.F., Kuznetsova A.I., Korobeinikova L.G., 1989. Metal Content in Baikal Fish. In: Israel Yu.A. (Ed.) Problems of Ecological Monitoring and Ecosystem Modelling. Gidrometeoizdat, Leningrad: 88-100.

Vinodhini R., Narayanan M., 2009. Heavy metal induced histopathological alterations in selected organs of the Cyprinus carpio L. (Common Carp). International Journal of Environmental Research 3(1): 95-100. DOI: 10.3906/vet0711-18

Vosylienè M.Z., Jankaitè A., 2006. Effect of heavy metal model mixture on rainbow trout biological parameters. Ekologija 4:12-17. Online: elibrary.lt/resursai/LMA/ Ekologija/Eko64/Eko64_05.pdf (accessed 14 Desemder 2019).

Wang X., Chu Z., Zha F., Liu S., Liu G., Dong Z., 2015. Determination of heavy metals in water and tissues of Crucian Carp (Carassius auratus Gibelio) collected from subsidence pools in Huainan Coal Fields (China). Ananlytical Letters 48(5): 861-877. DOI: 10.1080/00032719.2014.961606.

Wood C.M., Farrell A.P., Brauner C.J., 2012. Homeostasis and toxicology of non-essential metals. Academic, New York: 67-123.

Younis E.M., Al-Asgah A.N., Abdel-Warith A-W.A, Al-Mutairi A.A., 2015. Seasonal variations in the body composition and bioaccumulation of heavy metals in Nile tilapia collected from drainage canals in Al-Ahsa, Saudi Arabia. Saudi Journal of Biological Sciences 22: 443-447. DOI: 10.1016/j.sjbs.2014.11.020.

Zamana L.V., Strizhova T.A., Chechel L.P., 1998. Hydrochemical parameters of a lake and its catchment area (in Russian). In: Ecology of an inner-city water body. Publishing House Science SB RAS, Novosibirsk: 29-36.

Zamana L.V., Usmanova L.I., Usmanov M.T., 2011. Ecological and geochemical assessment of underground waters used by residents of the outskirts of Chita for decentral- 
ized supply (in Russian). Water: Chemistry and Ecology 12: 105-109.

Zholobova Y.S., Kushchiy N.A., Savon D.Y., Safronov A.E., 2016. Minimization of ecological impact by application of new technologies of coal preparation and mining waste disposal (in Russian). Gornyi Zhurnal 5: 109-112. DOI: 10.17580/gzh.2016.05.18.

Zhuldybina T.V., 2010. Hydrochemical regime of water streams of Chita Oblast (in Russian). Geography and Natural Resources 1: 99-102. 